Journal of Southeast Asian

\title{
Book Reviewed by Sarah Kahn: Bich Minh Nguyen. (2014). Pioneer Girl. New York, NY: Viking Press. 296pp. \$26.95 (Hardcover). ISBN: 978-0-670-025-09-1
}

Sarah Kahn

University of Montana, Missoula, sekahn7@gmail.com

Follow this and additional works at: https://docs.lib.purdue.edu/jsaaea

Part of the Education Commons

\section{Recommended Citation}

Kahn, Sarah (2016) "Book Reviewed by Sarah Kahn: Bich Minh Nguyen. (2014). Pioneer Girl. New York, NY: Viking Press. 296pp. \$26.95 (Hardcover). ISBN: 978-0-670-025-09-1," Journal of Southeast Asian American Education and Advancement: Vol. 11 : Iss. 1, Article 6.

DOI: $10.7771 / 2153-8999.1151$

Available at: https://docs.lib.purdue.edu/jsaaea/vol11/iss1/6

This document has been made available through Purdue e-Pubs, a service of the Purdue University Libraries. Please contact epubs@purdue.edu for additional information.

This is an Open Access journal. This means that it uses a funding model that does not charge readers or their institutions for access. Readers may freely read, download, copy, distribute, print, search, or link to the full texts of articles. This journal is covered under the CC BY-NC-ND license. 


\title{
JSAAEA \\ Journal of Southeast Asian American Education and Advancement
}

Volume 11 (2016)

\author{
WWW.JSAAEA.org
}

\section{Book Review}

Bich Minh Nguyen. (2014). Pioneer Girl. New York, NY: Viking Press. 296pp. \$26.95 (Hardcover). ISBN: 978-0-670-025-09-1

\section{Reviewed by \\ Sarah Kahn \\ University of Montana}

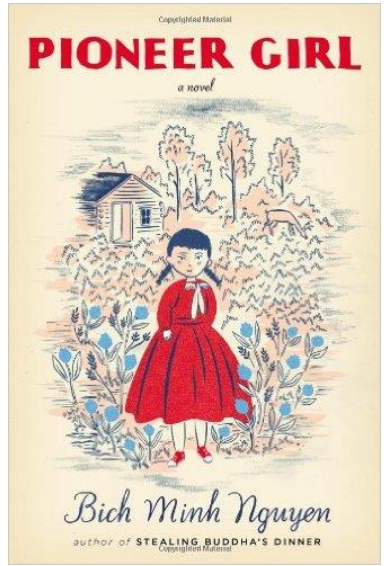

Pioneer Girl is a quintessential American family drama with a suspenseful mystery subplot. It is a pleasurable read, appropriate for high school students and adults. Most interestingly, it challenges American cultural assumptions, offers a fresh historical perspective, compellingly renders the experience of racism in small-town America, and presents a feminist critique of gendered paradigms, particularly as they relate to intersectionality and the experience of second-generation Americans. Pioneer Girl depicts the Vietnamese American experience and sheds light on the ways in which Asian Americans have been erased from the mainstream American cultural narrative.

The novel offers a fast-paced and engaging plot centering on a young Vietnamese woman contending with the economic and emotional challenges of life after graduating. With no job prospects and a recently acquired $\mathrm{PhD}$ in literature, Lee moves back home to live with her mother and grandfather, Tran and Ong Hai. Applying for postdocs and adjunct positions seems almost as bleak as continuing her research on Edith Wharton, something one of her professors advised her to abandon for "ethnic lit [which] was hotter right now and might make [her] more marketable" (p. 35). In her academic institution, Lee's adviser tokenizes her and commodifies her ethnicity; in her home, Lee's mother chastises her for not being traditional enough.

Having gone straight from college to graduate school, Lee has not lived at home for some time, but she returns to the same tension that she and her mother have always shared. Tran is controlling of and harsh with Lee, who feels she cannot do anything to gain her mother's approval. Lee's experience exemplifies the liminal experience of the children of immigrants, which she describes as the "chronic, lifetime second-generation problem. Looking forward and looking back, trying to locate the just-right space" (p. 292). Pioneer

\footnotetext{
(c)

SOBRERIGHISRESERVEDR Readers are free to copy, display, and distribute this article, as long as the work is attributed to the author(s)

and the Journal of Southeast Asian American Education \& Advancement, it is distributed for non-commercial purposes only,

and no alteration or transformation is made in the work. More details of this Creative Commons license are available at http://creativecommons.org/licenses/by-nc-nd/3.0/. All other uses must be approved by the author(s) or JSAAEA.

Journal of Southeast Asian American Education \& Advancement, Vol. 11 (2016) ISSN: 2153-8999
} 
Girl grapples with that problem as Lee tries to navigate the conflicting values of her mother's world, which values familial obligation and traditional female roles, and of her own world, which is peopled by young graduate students in literature, who value academic achievement and autonomy, but who have not yet found stable adult roles.

Part of this liminal experience involves rejection and oppression by both worlds. Not only does Lee experience disappointment from her mother, she is also the victim of racism in the middle-America towns in which she lives. As a child, Lee and her older brother, Sam, moved from city to city with their parents, who worked at a series of "wornout-looking Chinese buffets" (p. 48). Lee observes that these types of restaurants exist in every small town, a uniquely American creation that imitates a racist fantasy of Asian culture. Lee's parents, both Vietnamese, could work at "Chinese" buffets because "the customers didn't know the difference" (p. 52). As immigrants, Tran, her father, and her husband experienced terrible racism at these buffets, enduring it for the sake of providing for the family.

While contending with that racist American landscape and trying to achieve success and acceptance in a white, patriarchal academic world, Lee struggles to understand her own and her family's past. She begins to make connections with a memory that her grandfather often related to her as she was growing up. The memory is of an American woman he served at his café in Vietnam during the Vietnam War, before he and Tran emigrated. The woman, a friendly reporter named Rose who was sent to Saigon to write about "the war in Vietnam from a woman's point of view" (p. 2), left a broach painted with a fading picture of a house at Ong Hai's café. When Lee discovers that the woman her grandfather met may be the daughter of Laura Ingalls Wilder, the famous American pioneer sweetheart from the Little House on the Prairie books, she begins a research project that takes her in unexpected directions as she searches for the place where the dominant American narrative may have intersected with her own.

As the novel follows Lee's investigation, Nguyen integrates research on the Ingalls family with a somewhat postmodern narrative effect, allowing the book to integrate the fictional with the real. This braiding of narratives mimics Lee's endeavor to reveal the complex ways in which the histories of Vietnamese Americans lace the history of America. She challenges the concept that a single, dominant narrative can encompass the real American identity and uncovers many of the invisible and excluded smaller narratives.

Through Lee's investigation, Nguyen makes a patchwork of the American narrative, examining it as a valuable ideal, interrogating it as an exclusionary historical revision, and rewriting it in a new voice. In the Little House on the Prairie books, Almanzo, a brave frontier man, gives a pin with the image of a house and lake to his young bride-tobe, Laura. For them, the house represents the one he will build for her on the land they will conquer further West. For her whole life, Laura followed her father's persistent movement, failed crops, natural disasters, and misfortune driving them on again and again; now her husband promised to succeed on that same quest for an American home. In the iconic series, Almanzo's pin represents their American dream: a new frontier, a life forged there, a house and enough to eat, and perhaps the small luxuries of maple candy and hair ribbons. Even as she loves that romanticized American narrative, Lee acknowledges that the Ingallses had "a baseline white entitlement: the Indian land should, of course, be given to white settlers... any parcel of land out West might be theirs for the taking" (p. 71). As the 
stories of her own family become interwoven with the Ingalls Wilder stories of her childhood, Lee fights to understand her place in each.

Lee can relate to Laura's daughter Rose's desire to settle in a city, to live the American experience, after the hardship of moving from place to place with her mother. She can relate to having parents who fought to survive, to find a better life. The more intricately the stories of Lee's and Laura's families mirror one another, the more insistently the novel begs the questions: who writes these stories, and who decides which are told? Laura's story is about "failure, Manifest Destiny, and the tension between whites and the Osage Indians," and Lee questions the Ingalls's belief that the land is theirs by "right of whiteness." She points out that "the books never admit that Pa made any errors at all" (p. 126), though he made many. The series leaves out the story of the Osage Indians, edits away Pa's failures, and glorifies the white patriarch's right to Manifest Destiny. The stories of both Lee's and Laura's families are of parents setting out to achieve the American dream, persevering despite great adversity, and creating lives for themselves and their families, yet the American narrative reflects only Laura's. Lee notes that her "concept of American history had been unknowingly shaped just by reading those books, and ... they had rooted in me a paradox of pride and resentment - a desire to be included in the American story and a knowledge of the limits of such inclusion" (p. 248). Lee struggles to gain agency over her own narrative, and she travels across the country to answer her questions about the past.

As Lee grapples with her mother's expectations and her brother Sam's absence, Nguyen develops a feminist criticism of their respective roles. Just as Pa's failures were edited out of the Little House on the Prairie books, so too are Sam's flaws revised by Tran. While Lee undergoes intense scrutiny, her brother Sam gets away with great betrayals, and Lee laments, "he didn't see how easy he'd had it ... this was traditional, a Confucianinfluenced truth: the boy was entitled to more; the boy was subject to few verging on no obligations" (p. 20). She suffers under the incredible pressure to adhere to her mother's expectations: to be the good daughter and to carry the burden of her family's need while her brother gets only the pressure of their hopes.

The novel is engaging and entertaining, but it is also valuable in its social criticism and relateability. Nguyen handles the frustration and despair of young, unemployed adulthood with honesty and humor. Lee's experience illuminates the between-space of unemployment after graduation, where family and future are equal and opposing forces, and of being second generation, with two cultures that hold conflicting claims on her. Lee's story is that of the other Pioneer Girl, and hers is a marginalized voice reclaiming its place in the center of the American narrative.

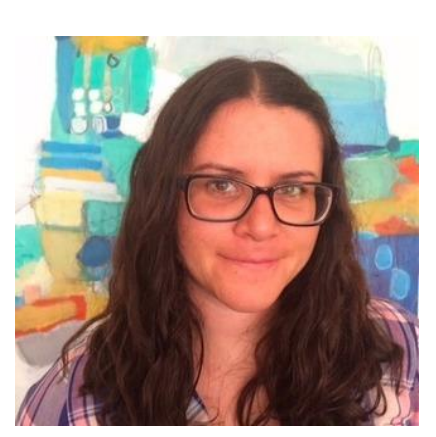

\section{About the Author}

Sarah Kahn has an MFA in fiction and an MA in literature from the University of Montana. She is the Program Officer at Humanities Montana and she teaches for the Missoula Writing Collaborative and tutors for Hughes Tutoring and Consulting. She founded Free Verse Writing Project, an organization that teaches literature and creative writing in juvenile detention centers across Montana. 

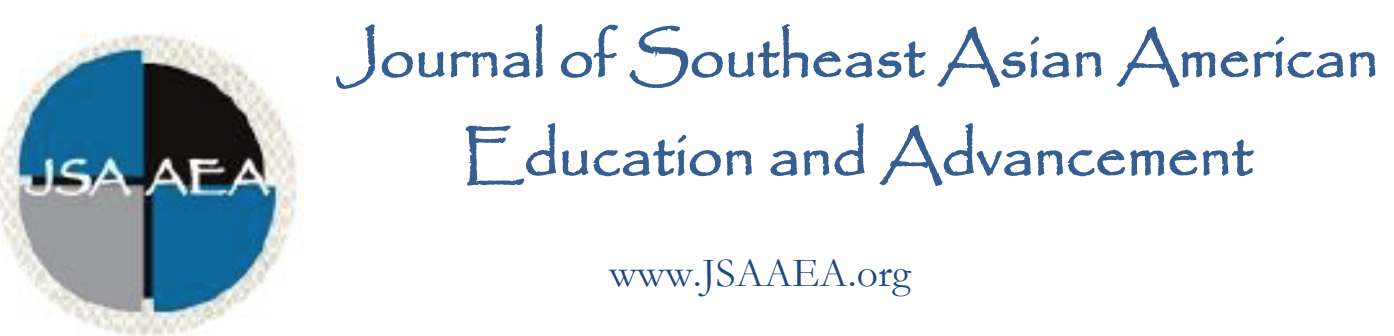

\title{
Editor
}

Dr. Wayne E. Wright

Purdue University

Associate Editors

Dr. Chhany Sak-Humphry

University of Hawaii at Manoa

Dr. Phitsamay Sychitkokhong Uy

University of Massachusetts, Lowell

\author{
Book Review Editor \\ Dr. Vichet Chhuon \\ University of Minnesota \\ Creative Works Editor \\ Bryan Thao Worra \\ Lao Assistance Center \\ Journal Manager \\ Sung Ae Kim \\ Purdue University
}

\section{Editorial Review Board}

Dr. Steve Arounsack

California State University, Stanislaus

Dr. Sovicheth Boun

The State University of New York at Fredonia

Dr. George Chigas

University of Massachusetts, Lowell

Dr. Hien Duc Do

San Jose State University

Dr. Sophal Ear

Occidental College

Dr. Nancy H. Hornberer

University of Pennsylvania

Dr. Zha Blong Xiong

University of Minnesota

Dr. Peter Nien-Chu Kiang

University of Massachusetts, Boston
Dr. Carl L. Bankston III

Tulane University

Dr. Phala Chea

Lowell Public Schools

Dr. Loan Dao

University of Massachusetts, Boston

Dr. Changming Duan

University of Missouri, Kansas City

Dr. Sothy Eng

Lehigh University

Dr. Vincent K. Her

University of Wisconsin, Eau Claire

Dr. Peter Tan Keo

New York University

Dr. Kevin K. Kumashiro

University of San Francisco 


\author{
Dr. Ha Lam \\ Eastern Mennonite University \\ Dr. Jonathan H. X. Lee \\ San Francisco State University \\ Dr. Monirith Ly \\ Royal University of Phnom Penh \\ Dr. Bic Ngo \\ University of Minnesota \\ Dr. Leakhena Nou \\ California State University, Long Beach \\ Dr. Mark Pfeifer \\ SUNY Institute of Technology \\ Dr. Loan T. Phan \\ University of New Hampshire \\ Dr. Kalyani Rai \\ University of Wisconsin, Milwaukee \\ Dr. Cathy J. Schlund-Vials \\ University of Connecticut, Storrs \\ Dr. Nancy J. Smith-Hefner \\ Boston University \\ Dr. Yer J. Thao \\ Portland State University \\ Dr. Monica M. Trieu \\ Purdue University \\ Dr. Silvy Un \\ Saint Paul Public Schools \\ Dr. Terrence G. Wiley \\ Center for Applied Linguistics
}

\author{
Dr. Ravy Lao \\ California State University, Los Angeles \\ Dr. Stacey Lee \\ University of Wisconsin, Madison \\ Dr. Sue Needham \\ California State University, Dominguez Hills \\ Dr. Max Niedzwiecki \\ Daylight Consulting Group \\ Dr. Clara Park \\ California State University, Northridge \\ Dr. Giang Pham \\ University of Massachusetts \\ Dr. Karen Quintiliani \\ California State University, Long Beach \\ Dr. Angela Reyes \\ Hunter College, City University of New York \\ Dr. Fay Shin \\ California State University, Long Beach \\ Dr. Christine Su \\ Ohio University \\ Dr. Alisia Tran \\ Arizona State University \\ Dr. Khatharya Um \\ University of California, Berkeley \\ Dr. Linda Trinh Vo \\ University of California, Irvine \\ Dr. Yang Sao Xiong \\ University of Wisconsin-Madison
}

\title{
Doctoral Student Editorial Review Board
}

\author{
Virak Chan \\ University of Texas at San Antonio \\ Annie BichLoan Duong \\ San Joaquin County Office of Education \\ Hoa Nha Nguyen \\ Boston College \\ Malaphone Phommasa \\ Marshall University \\ Molly Wiebie \\ The University of Texas at Austin \\ Anna H. Yang \\ University of Georgia
}

\author{
Keo Chea-Young \\ University of Pennsylvania \\ Dung Minh Mao \\ University of Minnesota \\ Thien-Huong Ninh \\ University of Southern California \\ Krissyvan Truong \\ Claremont Graduate University \\ Soua Xiong \\ San Diego State University \& \\ Claremont Graduate University
}

\author{
Linh Dang \\ University of Rochester
}

